\title{
Exploring audit assistants decision to leave the audit profession
}

Nellie Gertsson, J ohanna Sylvander, Pernilla Broberg and J osefine Friberg

The self-archived postprint version of this journal article is available at Linköping University Institutional Repository (DiVA):

http:/ / urn.kb.se/ resolve?urn=urn:nbn:se:liu:diva-143383

N.B.: When citing this work, cite the original publication.

Gertsson, N., Sylvander, J., Broberg, P., Friberg, J ., (2017), Exploring audit assistants decision to leave the audit profession, Managerial Auditing J ournal, 32(9), 879-898. https:// doi.org/ 10.1108/ MAJ -052016-1381

Original publication available at:

https:/ / doi.org/ 10.1108/ MAJ -05-2016-1381

Copyright: Emerald

http:// www.emeraldinsight.com/ 


\title{
Exploring audit assistants' decision to leave the audit profession
}

\author{
Nellie Gertsson \\ Department of Business Administration and Work Sciences, \\ Kristianstad University, Kristianstad, Sweden \\ Johanna Sylvander \\ Department of Management and Engineering, Business Administration Division, \\ Linköping University, Linkoping, Sweden \\ Pernilla Broberg \\ Department of Business Administration and Work Sciences, \\ Kristianstad University, Kristianstad, Sweden \\ Department of Management and Engineering, Business Administration Division, \\ Linköping University, Linkoping, Sweden \\ Josefine Friberg \\ Department of Business Administration and Work Sciences, \\ Kristianstad University, Kristianstad, Sweden
}

The order of the authors reflects their contribution. The authors are thankful to the current (at the time of the study) and former audit assistants who answered the survey, to the participants in the 39th EAA Annual Congress for their valuable comments on an earlier version of this paper and to the two anonymous reviewers for their valuable comments. 


\begin{abstract}
Purpose - The purpose of this paper is to explore why audit assistants leave the audit profession. By including both the perceptions held by audit assistants that left the audit profession and the perceptions of audit assistants still working in the audit profession, this study aims to explore how determinants of job satisfaction are associated with decisions to leave the auditing profession.
\end{abstract}

Design/methodology/approach - To explore the association between determinants of job satisfaction and decisions to leave, a survey was developed based on a literature review of determinants of job satisfaction. The survey was sent to both current and former Swedish audit assistants. The subsequent analysis was based on 231 complete surveys, of which 78 were from former audit assistants.

Findings - The main finding of this study is that there is a negative association between the choice to leave the profession and audit assistants' perceptions of the profession and between the choice to leave and work-life balance. Another finding was that met expectations and Big 4 were found to be positively associated with career change.

Originality/value - By approaching both current and former audit assistants, this study contributes to the literature on audit employee turnover by exploring determinants of actual career change, rather than turnover intentions. It also contributes by identifying and testing a variable not previously used as a determinant of job satisfaction; perceptions of the audit profession.

Key words Audit profession, Audit assistants, Job satisfaction, Career change, Employee turnover, Perceptions of the profession

Article classification research paper 


\section{Introduction}

A general problem in the audit profession is that many audit assistants [1] leave the profession after only a few years and before becoming certified auditors. According to Hiltebeitel and Leauby (2001), more than half of those who had chosen auditing as their first profession changed their career within three years. The audit profession anticipates some natural turnover due to their up or out system (Grey, 1998; Carrington, 2010). However, if too many audit assistants leave the profession, it could result in reduced expertise in the audit teams and be a potential threat to audit quality (cf. Hall and Smith, 2009; Chi et al., 2013) and perceived audit quality (cf. Svanström and Sundgren, 2012; Öhman, et al., 2012).

An important determinant of employee turnover and career change is job satisfaction (cf. Larkin, et al., 1999; Armstrong, 2006; Chi et al., 2013), which refers to the ability of a job to fulfil the desires, expectations, needs, or demands of an employee (Larkin et el., 1999). Prior studies have mainly focused on job satisfaction as a determinant of auditors' intention to leave the audit profession (e.g. Dole and Schroeder, 2001; Parker and Kohlmeyer, 2005; Chan et al., 2008; Hall and Smith, 2009; Herda and Lavelle, 2012; Nouri and Parker, 2013). However, even though employee turnover (e.g. Currivan, 1999) and behavioural research (e.g. Sutton, 1998) have shown that intentions correlate with behaviour, intentions cannot be used to fully explain actual behaviour. One reason is that intentions may change over time. If intentions and behaviour are measured at different times and intentions change, the correlation between the intentions and decision is invalid (cf. Sheeran, 2002). In addition, it takes time for intentions to manifest themselves in actual behaviour (Sutton, 1998). Since turnover studies are mainly based on survey data (e.g. Kim et al., 1996), the method used poses an additional problem. The respondents are not in an actual decision-making situation and may not have formed a decision to stay or leave, making their intentions hypothetical (cf. Sutton, 1998). Hence, exploring the association between determinants of job satisfaction and actual career change for audit assistants could provide valuable insights into how the profession could prevent unwanted turnover.

Three broad categories of job satisfaction determinants were identified from previous studies, namely, perceptions of the profession, work conditions and work environment. Although turnover and expectancy gap literature indicates that perceptions of the profession is a determinant of job satisfaction and turnover (e.g. Carcello, et al., 1991; Philips and Crane, 1996; Chia, 2003; Furnham et al., 2009), no studies have been identified that examine or explore the influence of these perceptions on the choice to leave the audit profession. Prior research has indicated that work conditions affect turnover intentions. For example, studies 
have shown that workload (e.g. Currivan, 1999; Gaertner, 1999) and stress (Kim et al., 1996) has a negative influence on job satisfaction, which in turn increases intentions to leave. Work environment is another factor affecting turnover in the audit profession (e.g. Gammie and Whiting, 2013). The literature in general suggests that a good work environment (e.g. Benke and Rhode, 1980; Carcello, et al., 1991), high degree of autonomy (Bamber and Iyer, 2009) and perceived justice (Parker and Kohlmeyer, 2005) increase job satisfaction and reduce intentions to leave.

To explore the association between job satisfaction determinants and actual decision to leave the audit profession, a survey was developed based on a literature review of determinants of job satisfaction. The survey was sent to both current and former Swedish audit assistants. The subsequent analysis was based on 231 complete surveys, of which 78 were from former audit assistants. A principal component analysis showed that determinants of job satisfaction consisted of four components in this context (work environment, work-life balance, perception of the profession and flexibility). These components were used in the empirical testing. The main finding of this study is that there is a negative association between work-life balance as well as perceptions of the profession and the choice to leave the profession. In addition, met expectations and Big 4 were found to be positively associated with career change. The results indicate that in order to retain employees, audit firms, especially the Big 4, must continuously manage not only employees' work-life balance and work conditions to keep them satisfied, but also their perceptions of the profession.

This study contributes to the turnover literature in audit firms by exploring how determinants of job satisfaction are associated with actual career change. By including former audit assistants as well as current audit assistants, it was able to explore the association between actual career change and determinants of job satisfaction. This is important since turnover intentions cannot fully explain actual turnover (cf. Sheeran, 2002). In addition, this study contributes by focusing on perceptions of the audit profession as a determinant of career change. Perceptions are important to consider since the environment of professional organizations has changed in recent decades, and the market for professional services has become more competitive (Brock, 2006). Professional organizations have moved from the traditional professional model, characterized by partnership, collegiality, informality and autonomous, unmanaged professional work, towards managed professional businesses characterized by managerialism, bureaucracy and commercialism (cf. Faulconbridge and Muzio, 2008; Broberg et al., 2013). That latter are characteristics often perceived as the antithesis of professionalism. However, the public, including job seekers, may still perceive professions as traditional 
professions (cf. Abbott, 1988). The mismatch between perceptions and actual professional work could thus be an important factor which influences job satisfaction and employee turnover in professional firms.

\section{Literature review}

In the extensive research on employee turnover, job satisfaction is argued to be an important determinant of turnover (e.g. Bullen and Flamholtz, 1985; Kim et al., 1996; Gaertner, 1999). Based on a literature review on a wide range of studies on determinants of job satisfaction and employee turnover, three broad categories of job satisfaction determinants that influence intentions to leave an occupation were identified: perceptions of the profession, work conditions, and work environment.

The image of a profession conveys information about the values for which it stands. These values legitimize the profession's existence through the creation of a public image and the perception of the profession as being socially acceptable (cf. Abbott, 1988). Literature argues that employees are attracted to organizations and professions that fit their personality and values (e.g. Ehrhart and Ziegert, 2005). Cable and Judge argue (1996) that a perceived misfit between personal and organizational values creates intentions to leave. Similarly, Abbott (1988) argues that the public professional image is decoupled from the workplace image, which suggests that a mismatch between these images and the values they convey might cause employee turnover. As professional organizations and professional work has, in general, become more bureaucratic and commercial in recent decades (cf. Faulconbridge and Muzio, 2008), the gap between the public professional image and the workplace image seems to have grown larger. Philips and Crain (1996) claim that organizations that are able to create realistic expectations amongst students have lower employee turnover and higher performance levels. At the same time, studies have shown that accounting students have unrealistic and mistaken perceptions (Carcello et al., 1991; Philips and Crain, 1996), including high expectations regarding certain attributes of the profession, such as status and prestige and sense of meaning, (Carcello et al., 1991). Compared to accounting staff, students perceive to a higher degree that accounting work involves frequent intellectual challenges and that the profession provides an important public service and should be held in high regard by the public (Carcello, et al., 1991). Since professional audit work is more guided by bureaucratic structures than professional judgements (Broberg, 2013) and since accountancy students join the profession with high expectations, it suggests a high potential for a perceived mismatch amongst employees. If this mismatch occurs, 
employees would develop low perceptions of the profession and develop turnover intentions. Although turnover and expectancy gap literature indicates that the perceptions of the profession is a determinant of job satisfaction and turnover, no studies have been identified that examine or explore the influence of these perceptions on the actual choice to leave the audit profession. Hence, it is particularly important to explore how perceptions of the audit profession influence actual turnover.

Work conditions as a determinant of job satisfaction and turnover have been widely studied. For example, studies have shown that workload (e.g. Currivan, 1999; Gaertner, 1999) and stress (Kim et al., 1996) have a negative effect on job satisfaction, which in turn increases intentions to leave. The workload for audit employees is especially high during the first quarter of the year when most audits and income-tax returns are finished (Sweeney and Summers, 2002). Even though Sweeney and Summers (2002) have shown that accountants have a relatively high stress tolerance, several studies have indicated that stress and work-life imbalance increases actual turnover (e.g. Law, 2010; Gammie and Whiting, 2013). However, the studies examining actual turnover have in general focused on gender differences (Pitman, et al., 1989, US sample) or only considered females' reasons for leaving (Law, 2010, Hong Kong sample; Gammie and Whiting, 2013, UK sample). Other auditing studies have shown that stress influences job satisfaction, but do not influence turnover intentions (Bullen and Flamholtz, 1985, US sample) and that there are no gender differences amongst auditors regarding job satisfaction and worklife balance (Umans, et al., 2016, Swedish sample). Hence, research overall suggests a negative relation between good working conditions and turnover, but results seems to vary due to differences in the studies' national and temporal contexts (cf. Eskildsen et al., 2004). Hence, there is a need to explore how perceived work conditions influence actual turnover in the Swedish audit context.

Work environment as a determinant of job satisfaction has been discussed in different ways in the literature, such as how work is designed and organized (Hackman and Oldman, 1976), as organizational reward systems (Bartol, 1979) and as the social work environment (i.e. the relationship with colleagues) (Bullen and Flamholtz, 1985). Hence, in this study the work environment is defined as including all these dimensions.

Studies examining influence of work environment have, for example, argued (Garg and Rastogi, 2006) and shown that varied and relevant work assignments are positively related to job satisfaction (Benke and Rhode, 1980; Carcello, et al., 1991). Carcello et al. (1991) showed that challenging and varied tasks are what audit assistant liked most about their work. However, studies have shown mixed results regarding audit assistants perceptions of work assignments 
depending on firm size. Larkin, et al. (1999) found that audit assistants in large firms were more satisfied with their work assignments than in small firms, whereas the results of Lee (2002) rather indicate the opposite. In addition, studies have shown that auditors value the opportunity to use their professional judgement (Bamber and Iyer, 2009) and that an increased level of decision making contributes to both greater job satisfaction and lower turnover intentions (Dole and Schroeder, 2001). Auditors who experience a high degree of autonomy are therefore more satisfied (Bamber and Iyer, 2009) and less likely to leave the profession (Pitman et al., 1998).

Gammie and Whiting (2013) found that women tend to leave the profession in search of a better working environment, with an unwillingness to accept organizational norms and guidelines being a common factor for leaving. However, a study by Albrecht et al. (1981) showed that not just female staff but audit staff in general feel unsatisfied regarding firm policy and administration. Being dissatisfied with the firm's policy, often leads to a feeling of being treated unfairly. Perceived injustice, especially in regards to pay and promotions, has been shown to have negative effects on job satisfaction and intentions to stay (Parker and Kohlmeyer, 2005).

Research has shown that a stronger social bond between employees and the firm reduces turnover (Herda and Lavelle, 2012). This bond is created through socialization, where the individual employee has adapted to the organizational culture through interactions with other employees (Chow et al., 2002; El-Rajabi, 2007). Being proud of what they do and where they work have been shown to positively affect employees’ job satisfaction (Knoop, 1994). Since one's occupation is a large part of one's social identity (Svensson and Ulfsdotter Eriksson, 2009), the level of pride can be seen as a measure of the strength of the social bond between an employee and the organization. Even though accounting firms are hierarchical (e.g. Otley and Pierce, 1996; Lee, 2002; Kosmala and Herrbach, 2006), bonds can be created across hierarchies because employees from different organizational levels often work in teams (Broberg, 2013), which requires a high degree of interaction and communication with both colleagues and clients (Benke and Rhode, 1980; Broberg, 2013). Audit assistants often have an older and more experienced colleague as a mentor (Hall and Smith, 2009), and those who receive mentoring support experience greater job satisfaction and are less likely to leave the profession (Hernbohn, 2004). Having good relationships with all parties in the workplace is also important. If relationships are strained, work becomes uncomfortable and strenuous (Benke and Rhode, 1980), which in the long run can lead to the choice to quit (Pitman et al., 1989). Although the literature in general thus suggests that a good work environment increases job satisfaction and 
reduces intentions to leave, there is a need to explore whether the same association applies to actual intentions to leave in the Swedish audit context.

The majority of the turnover studies use turnover intentions as a proxy for employee turnover, rather than examining actual turnover. It is a commonly assumed that intentions are a good proxy for behaviour in behavioural research and this has been done in several different fields such as marketing and health care (Sheeran, 2002; Chandon, et al., 2005). Even though employee turnover (e.g. Currivan, 1999) and behavioural research (e.g. Sutton, 1998) have shown that intentions correlate with behaviour, intentions cannot be used to fully explain actual behaviour. Meta-analytical studies have shown that intentions explain only $28 \%$ of the variance in behaviour on average (Sheeran, 2002). The explanations for the intention-behaviour gap are several. One is that intentions are not stable (Sheeran, 2002) and may change over time due to changes in context (Sutton, 1998). If intentions and behaviour are measured at different times and intentions change, the correlation between the intentions and the decision is invalid (cf. Sheeran, 2002). Another explanation is it takes time for intentions to manifest themselves in actual behaviour (Sutton, 1998), especially if it is an infrequent behaviour, such as deciding to change careers. Since turnover studies are mainly based on survey data (e.g. Kim et al., 1996), the method itself poses an additional problem. The respondents were not in an actual decisionmaking situation and may not have formed an intention to stay or leave, making the intentions hypothetical (cf. Sutton, 1998). In addition, in a hypothetical situation, respondents might not have thought through the consequences of the behaviour in question (cf. Sheeran, 2002) and the question itself might provoke the person to form intentions that they otherwise would not have formed (cf. Chandon, et al., 2005). Hence, exploring the association between actual career change and factors shown to affect turnover intentions could provide valuable insights.

To summarize, the literature review revealed three broad categories of job satisfaction: perceptions of the profession, work conditions and the work environment. Studies on work conditions and work environment generally show that good conditions and environment increase job satisfaction and reduce turnover intentions. However, there are some indications of national differences in how work conditions are perceived and some mixed results regarding gender differences. The job satisfaction category perceptions of the profession has not been considered in previous studies. Studies on employee turnover mainly use intentions as a proxy for behaviour. Thus there is a need to explore how these three job satisfaction determinants influence actual career change amongst audit assistants in Sweden. 


\section{Research methodology}

\subsection{Data collection}

The data was collected through an email survey during May 2014. Since there is no official list of audit assistants currently working, it was hard to determine the total size of the population and to identify ex- audit assistants. The process of identifying former audit assistants started with the use of the authors' own contacts and contacts in the Big 4 firms. A total of 310 email addresses of current audit assistants were collected from the auditing firms' web sites; however, the Big 4 firms rarely list audit assistants email addresses on their web pages. To ensure answers from Big 4 firms, a link to the survey with a cover letter was sent to all Swedish certified auditors with a registered email address at the Supervisory Board of Public Accountants in Sweden. A total of 3,137 certified auditors were registered on 5 March 2014, of which 3,047 auditors received the email with instructions to forward the link to the survey to current and former audit assistants. Data collection for this paper was performed as a part of a bachelor thesis (Friberg and Gertsson, 2014).

\subsection{Operationalization of the variables}

The dependent variable is audit assistants' career change. Hence, it was a dummy variable where audit assistants still working within the audit profession were coded 0 and those who had left the profession were coded 1.

The independent variables consist of three categories of job satisfaction determinants identified through the literature review: perceptions of the profession, work conditions and work environment. Perception of the profession has not been previously used as a variable in turnover studies. All statements measuring these categories were derived from theoretical concepts that in previous studies have been argued to or shown to influence job satisfaction and turnover (which are called career change factors in Table I). Even though there exists validated scales, for example, autonomy and workload (e.g. Currivan, 1999), the theoretical concepts were measured as one-item constructs on a 7-point Likert scale (see Table I). This was done in order to be able to include as many different determinants of job satisfaction as possible in the broader categories to reduce omitted variable bias. Even though the use of one-item measurements has been criticized because it lowers the validity of the scale (Sarstedt, et al., 2016), there are arguments for the choice. If the three identified theoretical determinants of job satisfaction were measured by the combination of different multi-items scales, it might have inflated the correlations between constructs due to common method bias (Bergkvist and Rossiter, 2007). In addition, a lengthier survey would probably have reduced the number of completed 
questionnaires (Bryman and Bell, 2011). The statements were, however, inspired by previous measurements, except for three cases where studies have not measured the career change factors directly, but the results indicated them to be relevant. Since the items measured different aspects of perceptions of the profession, work conditions and work environment previously addressed in the literature, the scales can be argued to have some content validity.

Based on expectancy theory, this study assumes that audit assistants have perceptions of the auditing profession created by the public image. If these are not supported by actual experience, the mismatch between the public image and the workplace image (cf. Abbott, 1988) could result in intentions to leave (Kim et al., 1996) and actual turnover (cf. Currivan, 1999). The auditing profession is known as a prestigious occupation with high status in society, where the work requires expert knowledge, which gives the individual a sense of meaning and creates both intellectual challenges and benefits to society (cf. Carcello et al., 1991; Chia, 2003). Hence, the profession symbolizes values such as status and prestige, sense of meaning, expertise and social benefits, around which mismatches can be created. The respondents were therefore asked the extent to which they associated the profession with these values (see Table I).

\section{Insert Table I about here}

Working conditions as a determinant of job satisfaction revolve around time factors and travel requirements (cf. Bullen and Flamholtz, 1985). In the audit context, time factors are especially crucial, since high workloads and overtime are common, especially during the busy season (Philips and Crain, 1996). Thus, items measuring the perceived degree of flexible and irregular work hours, workload and overtime were included (see Table I). Items measuring the perceived degree of stress and conflict between work and home life (work-life balance) were also included because they are closely connected to time factors and have been shown to affect turnover decisions (e.g. Law, 2010). Audit work has been depicted as involving a high degree of work-related travel (Philips and Crain, 1996), so one item concerned travel requirements (see Table I) [2].

The work environment as a determinant job satisfaction concerns the work itself (cf. Bullen and Flamholtz, 1985), firm routines and policies (Gammie and Whiting, 2013) pay, promotion (Gaertner, 1999), and career development (Twenge, et al., 2010). Work itself is measured by the extent to which the work involves varying job assignments and is autonomous (Furnham, et al., 
2009) and significant (cf. Bullen and Flamholtz, 1985). Significant work is defined as nonmenial work (Carcello, et al., 1991), which in the professional work setting can be interpreted as relevant work, since professional work by definition is non-menial (cf. e.g. Abbott, 1988). The perception of firm policies and routines has been shown to influence decisions to leave the profession (Gammie and Whiting, 2013; Larkin, et al., 1999), thus the respondents were asked about the extent to which they perceived the firm policies to be good. Pay and promotion are defined from a perceived justice perspective, since the perceived fairness of pay received is a more important determinant of job satisfaction than the actual amount of pay (cf. Gaertner, 1999). The respondents were thus asked to what degree they perceived both pay and promotion as fair (see Table I). Promotion opportunity has been shown to influence turnover intentions (cf. Bullen and Flamholtz, 1985), thus the respondents were asked if the work involved career development. The work environment also revolves around performance evaluation (Pitman et al., 1989), support from mentors (Carcello, et al., 1991), good relationships with colleagues (Furnham, et al., 2005) (see Table I for statements) and feeling a part of a group, which was measured by the extent to which the audit assistants were proud to be a part of the audit firm (e.g. Knoop, 1994).

This study used the degree to which expectations were met, gender, audit firm, office size and tenure as control variables. Since expectancy theory (e.g. Kim et al., 1996; Gagné and Deci, 2005) argues that unmet expectations regarding aspects of work increase turnover intentions and the likelihood of leaving, the respondents were asked to what degree their expectations of the profession before being hired were consistent with how they experienced the profession (Carcello, et al., 1991; Philips and Crain, 1996). Whether expectations were met controls for the expectations gap created by unrealistic or mistaken perceptions when entering the profession (cf. Carcello, et al., 1991; Larkin, et al., 1999). Gender was controlled for because studies have shown that women tend to leave the profession to a greater extent than men (e.g. Pitman et al., 1989; Morley, et al., 2002; Chi, et al., 2013). Audit firm was controlled for by using the variables office size (number of employees) and Big 4 (dummy variable) because studies have indicated a difference in job satisfaction (Patten, 1995) and perceptions of the work conditions (Clabaugh, et al., 2000) between employees working in larger firms versus those in smaller firms. In addition, studies have shown that Big 4 and non-Big 4 firms differ in work environments (Herbohn, 2005) and therefore attract employees driven by different aspects (Chia, 2003). Tenure was controlled for because it has been shown to positively affect job satisfaction (Bartol, 1979; Benke and Rhode, 1980). 
The variable age was used as a methodological control variable. Since the respondents were not asked how old they were when they quit, the age of the respondents when they left the profession could not be determined. However, since age has been shown to affect aspects of job satisfaction (Bartol, 1979; Benke and Rhode, 1980; Herbohn, 2004; Law, 2010), age was controlled for.

\subsection{Analysis}

The data was analyzed using binary logistic regression, since the dependent variable, career change, is dichotomous. However, the items measuring the independent variables were first subjected to a factor analysis to examine the underlying empirical structure, since this study includes a variable not previously tested in the employee turnover context. The factor analysis allowed exploration of the appropriateness of the independent variables in the empirical context of this study (cf. Bullen and Flamholtz, 1985).

\subsection{Sample}

In this study, the population was both current audit assistants and former audit assistants (i.e. individuals that have worked as audit assistants, but changed career paths and no longer work in the audit profession).

A total of 231 complete surveys were received, of which 78 were from former audit assistants. Since this study used a snowball-sampling technique, the sample may be biased. It is likely that current audit assistants (and certified auditors) could more easily contact audit assistants who had recently quit. There is also a possibility that the survey was snowballed within the social network of the contacted auditors and audit assistants (regardless of how they were contacted), which could lead to a sample of individuals sharing similar traits (Lopes, et al., 1996). T-tests were thus performed to identify possible sources of bias and the results are presented in the analysis section.

\section{Empirical results and analysis}

\subsection{Descriptive statistic: the respondents}

Of the 231 respondents, about 50\% were female. There is no statistically significant difference between current and former audit assistants in regards to gender. However, it is hard to determine whether our sample is representative, due to the lack of information on the total population of both groups. The mean age of the respondents was 32.8 years with a minimum of 21 years and a maximum of 65 years, where former audit assistants have a statistically higher mean age (37.46) compared to current audit assistants (30.37). Mean tenure was 42.7 months with a minimum of 2 months and a maximum of 325 months and no statistically difference was 
found between the groups. Of the respondents, $43.7 \%$ had worked or worked at a Big 4 firm, whereas a statistically higher proportion of the former audit assistants (61.5\%) had worked at a Big 4 firm. There was also a statistical difference in office size, where former audit assistants worked in larger offices (mean=268.03 employees) in comparison to current audit assistants (mean=73.16 employees). In regard to whether expectations were met, there was no statistical difference between the groups (mean current=4.48, mean former=4.51).

That former audit assistants worked more frequently in larger offices and Big 4 firms could be explained by a higher degree of employee turnover in larger audit firms (Chong and Monroe, 2015). Former audit assistants are on average older. Since tenure and age are correlated, older audit employees are more likely to have passed the auditor examination, which excluded older audit employees from the current audit assistants sample to a higher extent than from the sample of former audit assistants. Therefore, it seems that the differences between the groups are due more to the population studied than to a sampling bias.

\subsection{Descriptive statistics: the survey}

Descriptive statistics for the different items measuring the career change factors are shown in Table II, presenting mean and standard deviation for both current and former audit assistants and difference between the two groups' means. Work-life balance, overtime, and working hours were the factors that differed the most.

\section{Insert Table II about here}

\subsection{Factor analysis}

The data was explored through a principal component analysis (PCA) with direct oblimin rotation. The data was deemed suitable for factor analysis, since the ratio between observations and variables exceeded 10:1 (Hair et al., 2010). The PCA revealed five eigenvalues exceeding 1. In the five-component solution, the item work-related travel created a separate factor, which could be explained by the fact that this question was posed differently than the other items. Therefore, this item was excluded. The second PCA revealed a four-component solution, explaining a total of $60.12 \%$ of the variance.

The factor analysis showed that one of the three independent variables, work conditions, had separated into two components and that the three work environment items did not group in the intended factor. The separation of work conditions suggests that the variable consists of two 
subcomponents, and the subcomponents were thus used in the analysis to avoid inflated correlations due to common method bias (Bergkvist and Rossiter, 2007). The first component consists of eight work environment items (see Table III). The second component includes four of the working condition items connected to stress and overtime and thus classified as worklife balance. The third component consists of the four perceptions of the profession items and career development. That career development is perceived as a part of the professional image rather than as a work environment aspect is reasonable, since professions tend to be characterized by certain career paths (cf. Abbott, 1988). The fourth component consists of two work condition items and two work environment items. These items revolve around flexibility, autonomy, workload (having enough time to do one's job) and varied work assignments, which all, to some extent, revolve around flexibility. Hence, this component is classified as flexibility. Cronbach's alpha for all components (see Table III) exceeds the minimum value of 0.6 for exploratory studies (Hair et al., 2010). Factor scores were made based on the PCA, which were used in the following regression as independent variables.

\section{Insert Table III about here}

\subsection{Logistic regression}

Firstly, a collinearity diagnostics test was performed to check for multicollinearity. Even though there is a significant correlation between the variables age and tenure, as well as between the independent variables, the highest VIF-value when all variables are included is 1.58 , which is well below the recommended cut-off point of 10 (Pallant, 2013).

\section{Insert Table IV about here}

The analysis in Table IV shows that work-life balance as well as perception of the profession have a significant negative association with career change. The results also show an indication that flexibility is negatively associated with career change; however it is not significant on a conventional level, but close to it ( $\mathrm{p}$-value $=0.051$ ). The odds ratios indicate that, in comparison to work-life balance, perceptions of the profession seem to be more associated with the decision 
to leave in relative terms. In other words, current audit assistants experience a better work-life balance and have higher perceptions of the profession in comparison to how former audit assistants experienced it. It seems as though perceptions of the profession as being less prestigious, meaningful and intellectually stimulating triggers employees to take the decision to leave the profession to a higher extent than does lower work-life balance. Work environment is not significant, indicating that social relationships with colleagues and mentors, organizational pride and perceived justice in pay and promotion are not associated with the career change choice.

Met expectations have a positive association with career change, which is the opposite of what theory predicts. These results indicate rather that those with low expectation gaps are more inclined to leave the profession. The results also show that age, tenure and being employed at a Big 4 firm are statistically significant, where age and being employed at a Big 4 firm have a positive association with career change, whereas tenure has a negative but relatively small association with career change. No conclusions could be drawn on how age affects career change because age was only used as a methodological control variable. Gender is not significant in the regression; however, a subgroup analysis (not reported here) indicated that work-life balance and perceptions of the profession have a negative association with career change for men and not for women, whereas flexibility has a negative association with career change for women and not men.

\section{Conclusions and discussion}

This paper contributes to the turnover literature in audit firms, in particular to the understanding of how determinants of job satisfaction are associated with the career change decision amongst audit assistants. The main findings are that there is a negative association between work-life balance as well as perceptions of the profession and the choice to leave the audit profession, where the decision seems to be most associated with the perceptions of the profession. In addition, met expectations and Big 4 firms were found to be positively associated with career change.

To have low perceptions of the profession is to consider the work as not being prestigious, having no meaning or societal benefits and not providing intellectual stimulus or career development. Thus the results have practical implications. They indicate that the audit firms need to work continuously on how their employees view the profession (in terms of status and prestige, sense of meaning, expertise, societal benefits, and career development) in addition to providing good working conditions, such as work-life balance and flexibility. To retain 
employees, it is important to give them a true and fair view of the profession. Hence, audit firms should not only treat a high turnover in audit assistants as an important issue to deal with in order to reduce investing time and money in "the wrong person”. It should also be treated as an important signal for the firms to explore the professional organizational values they stand for, since the results imply that the mismatch between their public professional image (i.e. their values) and the workplace values experienced might reduce job satisfaction and increase employee turnover.

This study indicates that work conditions have the same association with actual behaviour as with intentions to leave. For example, studies have shown that work-life balance (e.g. Law, 2010; cf. Gammie and Whiting, 2013) and flexibility (e.g. Currivan, 1999; cf. Gammie and Whiting, 2013) can increase job satisfaction and reduce employee turnover. However, the results in this study indicate that the work environment is not associated with a decision to leave, which previous literature on turnover intentions has indicated (e.g. Gaertner, 1999). That the result show no association between work environment and actual behaviour could be due to the low variation in perceptions of the work environment between the two respondent groups.

This study also contributes to the literature on audit assistants, especially regarding what aspects of job satisfaction that are associated with their decision to leave the profession. Thus, the result of this study also provide insights to the profession. By paying more attention to the aspects associated with career change the profession would be able, to some extent, to predict and prevent unwanted turnover, and thereby reduce a potential threat to audit quality and perceived audit quality.

This study has several limitations. Because the surveys were sent out during the busy season, the results might be biased, mainly regarding work-life balance. Therefore, this study should be replicated at a different period to validate the results. Since perceptions of work conditions seem to be influenced by culture (cf. Eskildsen et al., 2004), our results may not be generalized to cultures that differ substantially from the Swedish culture. There is also an inherent risk that the former audit assistants' answers reflected their justification for leaving the profession rather than how they actually perceived their work experience when employed. Furthermore, their answers could have been affected by not accurately remembering their experiences (cf. Alvesson, 2011). Thus our results should be interpreted with caution. Another limitation is that the current audit assistants may have intended to leave and may have done so after the study was conducted. In addition, both current and former audit assistants may have entered the profession intending to stay only for a brief period and use their audit firm 
experience as a first step in their career (cf. Steenackers, Breesch, and Hardies, 2016). These aspects should be controlled for in future studies.

The exploratory model used in this study is rather simplistic. Both the creation of job satisfaction and the decision to leave the profession are complex processes that ought to be influences by many difference factors. Thus, future research could benefit from comparing current and former audit employees' perceptions and actions using more complex models with different moderating and mediating variables. Qualitative research might provide different insights on why individuals choose to leave a profession. Future research could use Mills' (1940) vocabulary of motives to deepen the understanding of how audit employees perceive the audit profession and their motives for leaving the profession.

Since perceptions of the profession are found to be negatively associated with actual career change, future research should further investigate how perceptions of the profession influence turnover. For example, how are perceptions formed? Since potential and current employees meet the profession through the audit firms (since they embody the profession), perceptions of the profession are likely to be influenced by the individual audit firms. The audit firms are said to have different corporate cultures and can thus influence perceptions in different ways. The question is how do these different corporate cultures in combination influence potential employees' perceptions of the profession? Is there a mismatch between perceptions and actual professional work and if so, does the mismatch influence job satisfaction and turnover in the same way, regardless of the "source" of the mismatch (i.e. the particular aspect or aspects that create the mismatch)?

This study indicates that work-life balance is important for audit assistant when deciding to stay or leave. However, for audit firms characterized by an uneven workload and overtime, what their employees see as work-life balance might need further investigation. Balance can mean different things for different people and balance can be achieved in different ways. Considering that the newer generations of workers are said to value leisure and work-life balance more than previous generations (Twenge, et al. 2010) investigating what work-life balance actually is for audit employees and how it affects their work could provide valuable insights. 


\section{Notes}

1. In this study, audit assistants are defined as auditors that have not yet passed the auditor exam. We considered using the term junior auditor, which is a more common term in the literature. However, some studies focus on junior auditors, who are junior in terms of tenure (i.e. with tenure below two years; see for example Pradana and Salehudin, 2015). Since we do not focus on junior auditors in that sense, we have chosen to use the term audit assistants to avoid confusion.

2. Note that items regarding stress, overtime et cetera can be worded in different ways and measure either the presence of or the lack of an aspect. We worded the items in both ways; therefore we have recoded some items to measure the lack of the aspect in question, so that high agreement with the statement means, for example, low presence of stress.

\section{References}

Abbott, A. (1988), The System of professions: An Essay on the Division of Expert Labor, The University of Chicago Press, Chicago.

Albrecht, W. S., Brown, S. W. and Field, D. R. (1981), "Toward Increased Job Satisfaction of Practicing CPAs", Journal of Accountancy, Vol. 152 No. 2, pp. 61-66.

Armstrong, M. (2006), A handbook of human resource managemant practice, $10^{\text {th }}$ ed., Kogan Page, London.

Alvesson, M. (2011), Interpreting interviews, SAGE Publications Inc, London.

Bamber, M. and Iyer, V. (2009), "The effect of auditing firms' tone at the top on auditors' job autonomy, organizational-professional conflict, and job satisfaction", International Journal of Accounting, Vol. 17 No. 2, pp. 136-150.

Bartol, K.M. (1979), "Individual versus organizational predictors of job satisfaction and turnover among professionals", Journal of Vocational Behavior, Vol. 15 No. 1, pp. $55-67$.

Benke, R.L. and Rhode, J.G. (1980), "The job satisfaction of higher level employees in large certified public accounting firms", Accounting, Organizations and Society, Vol. 5 No. 2, pp. 187-201. 
Bergkvist, L. I. and Rossiter, J. (2007), "The predictive validity of multiple-item versus single-item measures of the same constructs", Journal of Marketing Research, Vol. 44 No. 2, pp. 175-184.

Broberg, P. (2013), The Auditor at Work: A Study of Auditor Practice in Big 4 Audit Firms, Doctoral Dissertation, School of Economics and Management, Lund University.

Broberg, P., Umans, T. and Gerlofstig, C. (2013), "Balance between auditing and marketing: An explorative study", Journal of International Accounting, Auditing and Taxation, Vol. 22 No. 1, pp. 57-70.

Brock, D. M. (2006), "The changing professional organization: A review of competing archetypes", International Jornal of Management Reviews, Vol. 8 No. 3, pp. 157-174.

Bryman, A., and Bell, E. (2011), Business Research Methods, $3^{\text {rd }}$ ed., Oxford University Press Inc, New York, NY.

Bullen, M. L. and Flamholtz, E. G. (1985), "A theoretical and empirical investigation of job satisfaction and intended turnover in the large CPA firm", Accounting, Organizations and Society, Vol. 10 No. 3, pp. 287-302.

Cable, D. M. and Judge, T. A. (1996), "Person-organization fit, job choice decisions, and organizational entry", Organizational behavior and human decision processes, Vol. 67 No. 3, pp. 294-311.

Carcello, J. V., Copeland Jr., J.E., Hermanson, R.H. and Turner, D.H. (1991), "A public accounting career: The gap between student expectations and accounting staff experiences", Accounting Horizon, Vol. 5 No. 3, pp. 1-11.

Carrington, T. (2010), Revision, Liber AB, Malmö.

Chan, C. C., Monroe, G. S., Ng, J. and Tan, R. (2008), "Effects of employee support on junior accountants' job attitudes and intention to quit", Australian Accounting Review, Vol 18 No. 2, pp. 149-160.

Chandon, P., Morwitz, V. G. and Rein, W. J. (2005), "Do Intentions Really Predict Behavior? Self-Generated Validity Effects in Survey Research", Journal of Marketing, Vol. 69 No. 2, pp. 1-14. 
Chi, W., Hughen, L., Lin, C.-J. and Lisic, L. (2013), "Determinants of audit staff turnover: Evidence from Taiwan", International Journal of Auditing, Vol. 17 No. 1, pp. 100112.

Chia, Y. M. (2003), "Career drivers of junior auditors: an exploratory study", Managerial Auditing Journal, Vol. 18 No. 2, pp. 100-111.

Chong, V.K. and Monroe, G.S. (2015), "The impact of the antecedents and consequences of job burnout on junior accountants' turnover intentions: a structural equation modelling approach", Accounting \& Finance, Vol. 55 No. 1, pp. 105-132.

Chow, C.W., Harrison, G.L., McKinnon, J.L. and Wu, A. (2002), "The organizational culture of public accounting firms: evidence from Taiwanese local and US affiliated firms", Accounting, Organizations and Society, Vol. 27 No. 4, pp. 347-360.

Clabaugh, C.A., Monroe, G.S. and Soutar, G.N. (2000), "Supervisory factors affecting job satisfaction in public accounting firms", Australian Accounting Review, Vol. 10 No. 20, pp. 65-72.

Currivan, D.B. (1999), "The causal order of job satisfaction and organizational commitment in models of employee turnover", Human Resource Management Review, Vol. 9 No. 4, pp. 495-524

Dole, C. and Schroeder, R. G. (2001), "The impact of various factors on the personality, job satisfaction and turnover intentions of professional accountants", Managerial Auditing Journal, Vol. 16 No. 4, pp. 234-245.

Ehrhart, K. H. and Ziegert, J. C. (2005), "Why are individuals attracted to organizations?", Journal of Management, Vol. 31 No. 6, pp. 901-919.

El-Rajabi, M.T. (2007), "Organizational-professional conflict and culture differences among auditors in emerging markets: The case of Jordan and Kuwait", Managerial Auditing Journal, Vol. 22 No. 5, pp. 485-502.

Faulconbridge, J. and Muzio, D. (2008), "Organizational professionalism in globalizing law firms", Work Employment and Society, Vol. 22 No. 1, pp.7-25.

Eskildsen, J.K., Kristensen, K. and Westlund, A.H. (2004), "Work motivation and job satisfaction in the Nordic countries", Employee Relations, Vol. 26 No. 2, pp. 122-136. 
Friberg, J. and Gertsson, N. (2014), Hur förklaras karriärbyten bland revisorsassistenter? En jämförande studie av uppfattningar mellan nuvarande och före detta revisorsassistenter [Determinants of turnover in junior auditors: a comparative study of perceptions among present and former junior auditors]. (Bacheor Thesis, Kristianstad University, Sweden)

Furnham, A., Eracleous, A. and Chamorro-Premuzic, T. (2009), "Personality, motivation and job satisfaction: Hertzberg meets the Big Five", Journal of Managerial Psychology, Vol. 24 No. 8, pp. 765-779.

Furnham, A., Petrides, K. V., Tsaousis, I., Pappas, K. and Garrod, D. (2005), "A crosscultural investigation into the relationship between personality traits and work values", The Journal of Psychology, Vol. 139 No. 1, pp. 5-32.

Gaertner, S. (1999), "Structural determinants of job satisfaction and organizational commitment in turnover models", Human Resource Management Review, Vol. 9 No. 4, pp. 479-493.

Gagné, M. and Deci, E. L. (2005), "Self-determination theory and work motivation", Journal of Organizational Behavior, Vol. 26 No. 4, pp. 331-362.

Gammie, E. and Whiting, R. (2013), "Women accountants: Is the grass greener outside the profession?", The British Accounting Review, Vol. 45 No. 2, pp. 83-98.

Garg, P. and Rastogi, R. (2006), "New model of job design: Motivating employees' performance", Journal of Management Development, Vol. 25 No. 6, pp. 572-587.

Grey, C. (1998), "On being a professional in a "Big Six" firm", Accounting, Organizations and Society, Vol. 23 No. 5/6, pp. 569-587.

Hackman, J.R. and Oldham, G.R. (1976), "Motivation through the design of work: Test of a theory", Organizational Behavior and Human Performance, Vol. 16 No. 2, pp. 250279.

Hair, J.F., Black, W.C., Babin, B.J. and Anderson, R.E. (2010), Multivariate Data Analysis: A Global Perspective, $7^{\text {th }}$ ed., Pearson Education, Upper Saddle River, NJ.

Hall, M. and Smith, D. (2009), "Mentoring and turnover intentions in public accounting firms: A research note", Accounting, Organizations and Society, Vol. 34 No. 6, pp. 695-704. 
Herbohn, K. (2004), "Informal mentoring relationships and the career processes of public accountants", The British Accounting Review, Vol. 36 No. 4, pp. 369-393.

Herbohn, K. (2005), "Job satisfaction dimensions in public accounting practice", Accounting Research Journal, Vol. 18 No. 2, pp. 63-82.

Herda, D. N. and Lavelle, J. J. (2012), "The auditor-audit firm relationship and its effect on burnout and turnover intentions", Accounting Horizons, Vol. 26 No. 4, pp. 707-723.

Hiltebeitel, K. and Leauby, B. (2001), "Migratory patterns of entry-level accountans", The CPA Journal, Vol. 71 No. 4, pp. 54-56.

Kim, S.W., Price, J.L., Mueller, C.W. and Watson, T.W. (1996), "The determinants of career intent among physicians at a US Air Force hospital", Human Relations, Vol. 49 No. 7, pp. 947-976.

Knoop, R. (1994), "Work values and job satisfaction", The Journal of Psychology, Vol. 128 No. 6, pp. 683-690.

Kosmala, K. and Herrbach, O. (2006), "The ambivalence of professional identity: On cynicism and jouissance in audit firms", Human Relations, Vol. 59 No. 10, pp. 13931428.

Larkin, J. M., Leauby, B. A. and Hiltebeitel, K. M. (1999), "Early employment experiences of accountants: Initial placement, job satisfaction, and migratory patterns", The Review of Accounting Information Systems, Vol. 3 No. 3, pp. 63-72.

Law, P. (2010), "Examination of the actual turnover decisions of female auditors in public accounting: Evidence from Hong Kong", Managerial Auditing Journal, Vol. 25 No. 5, pp. 484-502.

Lee, B. (2002), "Professional socialisation, commercial pressures and junior staff's timepressured irregular auditing - A contextual interpretation", The British Accounting Review, Vol. 34 No. 4, pp. 315-333.

Lopes, C. S., Rodrigues, L. C. and Sichieri, R. (1996), "The Lack of Selection Bias in a Snowball Sampled Case-Control Study on Drug Abuse", International Journal of Epidemiology, Vol. 25 No. 6, pp. 1267-1270. 
Mills, C.W. (1940), "Situated actions and vocabularies of motive", American Sociological Review, Vol. 5 No. 6, pp. 904-913.

Morley, C., Bellamy, S., Jackson, M. and O'Neil, M. (2002), "Attitudinal barriers to women's career progression in accounting in Australia", Australian Accounting Review, Vol. 12 No. 26, pp. 64-72.

Nouri, H. and Parker, R. J. (2013), "Career growth opportunities and employee turnover intentions in public accounting firms", The British Accounting Review, Vol. 45 No. 2, pp. 138-148.

Otley, D.T. and Pierce, B.J. (1996), "The operation of control systems in large audit firms", Auditing: A Journal of Practice and Theory, Vol. 15 No. 2, pp. 65-84.

Pallant, J. (2013), SPSS Survival Manual: A Step by Step Guide to Data Analysis Using IBM SPSS, $5^{\text {th }}$ ed., McGraw-Hill, Maidenhead.

Parker, R. J. and Kohlmeyer, J. M. (2005), "Organizational justice and turnover in public accounting firms: a research note", Accounting, Organizations and Society, Vol. 30 No. 4, pp. 357-369.

Patten, D.M. (1995), "Supervisory actions and job satisfaction: An analysis of differences between large and small public accounting firms", Accounting Horizons, Vol. 9 No. 2, pp. 17-28.

Philips, C.R. and Crain, J.L. (1996), "Job duties and responsibilities in public accounting: are student expectations unrealistic?", Education + Training, Vol. 38 No. 9, pp. 21-26.

Pitman, M.K., Gaertner, J.F. and Hemmeter, P.E. (1989), "A study of male and female employee turnover in public accounting firms", The Journal of Applied Business Research, Vol. 5 No. 3, pp. 10-15.

Pradana, A. and Salehudin, I. (2015), "Work overload and turnover intention of junior auditors in Greater Jakarta, Indonesia", The South East Asian Journal of Management, Vol. 9 No. 2, pp 108-124

Sarstedt, M., Diamantopoulos, A., Salzberger, T. and Baumgartner, P. (2016), "Selecting single items to measure doubly concrete constructs: A cautionary tale", Journal of Business Research, Vol. 69 No. 8, 3159-3167. 
Sheeran, P. (2002), "Intention-Behavior Relations: A Conceptual and Empirical Review", European Review of Social Psychology, Vol. 12 No. 1, pp. 1-36.

Steenackers, K., Breesch, D. and Hardies, K. (2016), "Auditors' length of stay in their first audit firm - An empirical study for the Belgian audit profession using survival analysis", paper presented at the 6th EIASM Workshop on Audit Quality, 30th September, Florence, Italy.

Sutton, S. (1998), "Predicting and Explaining Intentions and Behavior: How Well Are We Doing?", Journal of Applied Social Psychology, Vol. 28 No. 15, pp. 1317-1338.

Svanström, T. and Sundgren, S. (2012), "The demand for non-audit services and auditorclient relationships: Evidence from Swedish small and medium-sized enterprises", International Journal of Auditing, Vol. 16 No. 1, pp. 54-78.

Svensson, L. G. and Ulfsdotter Eriksson, Y. (2009), Yrkesstatus. En sociologisk studie av hur yrken uppfattas och värderas [Occupational status: A sociolgical study of how occupations are perceived and valued] (Research report no. 140 from the Department of Sociology, Gothenburg University), Gothenburg, University of Gothenburg, available at http://gupea.ub.gu.se/dspace/handle/2077/19737 (access date: 2017-06-30)

Sweeney, J.T. and Summers, S.L. (2002), "The effect of the busy season workload on public accountants' job burnout", Behavioral Research in Accounting, Vol. 14 No. 1, pp. 223-245.

Twenge, J.M., Campbell, S.M., Hoffman, B.J. and Lance, C.E. (2010), "Generational differences in work values: Leisure and extrinsic values increasing, social and intrinsic values decreasing", Journal of Management, Vol. 36 No. 5, pp. 1117-1142.

Umans, T., Broberg, P., Schmidt, M., Nilsson, S. and Olsson, E. (2016), "Feeling well by being together: Study of Swedish auditors", Work, Vol. 54 No. 1, pp. 79-86.

Öhman, P., Häckner, E. and Sörbom, D. (2012), "Client satisfaction and usefulness to external stakeholders from an audit client perspective", Managerial Auditing Journal, Vol. 27 No. 5, pp. 477-499.

\section{Corresponding author}

Pernilla Broberg can be contacted at: pernilla.broberg@hkr.se 
Table I.

Career change factors

\begin{tabular}{|c|c|c|c|c|}
\hline $\begin{array}{l}\text { Independent } \\
\text { variables }\end{array}$ & $\begin{array}{l}\text { Career change } \\
\text { factor }\end{array}$ & Identified e.g. in & $\begin{array}{l}\text { Measurement items (Scale } 1= \\
\text { strongly disagree to } 7=\text { strongly } \\
\text { agree) }\end{array}$ & Original statements \\
\hline \multirow{4}{*}{$\begin{array}{l}\text { Perceptions of } \\
\text { the profession }\end{array}$} & $\begin{array}{l}\text { Status and } \\
\text { prestige }\end{array}$ & $\begin{array}{l}\text { Chia (2003); Carcello et al. (1991); } \\
\text { Furnham et al. (2009) }\end{array}$ & $\begin{array}{l}\text { I associate the auditing profession with status } \\
\text { and prestige. }\end{array}$ & $\begin{array}{l}\text { "The public accounting profession deserves to be held in high regard by the } \\
\text { general public." (Carcello et al., 1991); "Status - a job that is generally } \\
\text { recognized as 'high status' in our society." (Furnham et al., 2009) }\end{array}$ \\
\hline & Sense of meaning & Chia (2003) & $\begin{array}{l}\text { I associate the auditing profession with sense } \\
\text { of meaning. }\end{array}$ & Own developed statement \\
\hline & Expertise & Carcello et al. (1991); Chia (2003) & $\begin{array}{l}\text { I associate the auditing profession with } \\
\text { intellectual challenges. }\end{array}$ & $\begin{array}{l}\text { "Public accounting provides frequent intellectual challenges." (Carcello et al., } \\
\text { 1991) }\end{array}$ \\
\hline & Societal benefits & $\begin{array}{l}\text { Carcello et al. (1991); Furnham et al. } \\
\text { (2009) }\end{array}$ & $\begin{array}{l}\text { I associate the auditing profession with societal } \\
\text { benefits. }\end{array}$ & $\begin{array}{l}\text { "Public accounting provides an important public service." (Carcello et al., } \\
\text { 1991); "Contribution to society - a job that allows me to work for a good } \\
\text { cause" (Furnham et al., 2009) }\end{array}$ \\
\hline \multirow{7}{*}{$\begin{array}{l}\text { Work } \\
\text { conditions }\end{array}$} & Workload & $\begin{array}{l}\text { Carcello et al. (1991); Currivan (1999); } \\
\text { Gaertner (1999) }\end{array}$ & $\begin{array}{l}\text { The work as an audit assistant } \\
\text { involves/involved enough time to perform my } \\
\text { job assignments. }\end{array}$ & $\begin{array}{l}\text { "Adequate time is provided to complete job responsibilities." (Carcello et al., } \\
\text { 1991); "I do not have enough time to get everything done on my job" } \\
\text { (Currivan, 1999) }\end{array}$ \\
\hline & Overtime & Carcello et al. (1991) & $\begin{array}{l}\text { The work as an audit assistant } \\
\text { involves/involved unreasonable demand for } \\
\text { overtime. (reversed statement) }\end{array}$ & $\begin{array}{l}\text { "Firm has a clearly articulated and honored overtime policy." (Carcello et al., } \\
\text { 1991) }\end{array}$ \\
\hline & Flexibility & $\begin{array}{l}\text { Gammie \& Whiting (2013); Furnham et } \\
\text { al. (2009) }\end{array}$ & $\begin{array}{l}\text { The work as an audit assistant } \\
\text { involves/involved flexible work hours. }\end{array}$ & $\begin{array}{l}\text { "Flexibility - a job that allows me to work flexible hours to suit my personal } \\
\text { needs." (Furnham et al., 2009) }\end{array}$ \\
\hline & Working hours & $\begin{array}{l}\text { Philips \& Crain (1996); Bullen \& } \\
\text { Flamholtz (1985) }\end{array}$ & $\begin{array}{l}\text { The work as an audit assistant } \\
\text { involves/involved uneven work hours. } \\
\text { (reversed statement) }\end{array}$ & $\begin{array}{l}\text { "Staff accountants often work longer than normal hours from January } 1 \text { to } \\
\text { April 15." (Philips \& Crain, 1996) }\end{array}$ \\
\hline & Stress & $\begin{array}{l}\text { Chi et al. (2013); Law (2010); Kim et al. } \\
\text { (1996) }\end{array}$ & $\begin{array}{l}\text { The work as an audit assistant } \\
\text { involves/involved a high degree of stress. } \\
\text { (reversed statement) }\end{array}$ & Own developed statement \\
\hline & Work-life balance & $\begin{array}{l}\text { Law (2010); Twenge et al. (2010); } \\
\text { Furnham et al. (2009) }\end{array}$ & $\begin{array}{l}\text { I experience/experienced a balance between } \\
\text { private life and work life. }\end{array}$ & $\begin{array}{l}\text { "A job that leaves a lot of time for other things in your life" (Twenge et al, } \\
\text { 2010); "Balance - a job that allows me to lead a balanced life." (Furnham et al., } \\
\text { 2009) }\end{array}$ \\
\hline & $\begin{array}{l}\text { Work-related } \\
\text { travels }\end{array}$ & $\begin{array}{l}\text { Philips \& Crain (1996); Gammie \& } \\
\text { Whiting (2013) }\end{array}$ & $\begin{array}{l}\text { The work as an audit assistant } \\
\text { involves/involved demand for work-related } \\
\text { travels (reversed statement). }\end{array}$ & $\begin{array}{l}\text { "Staff accountants who work in auditing generally do a great deal of work- } \\
\text { related travel." (Philips \& Crain, 1996) }\end{array}$ \\
\hline
\end{tabular}


Independent Career change variables

\begin{tabular}{|c|c|c|}
\hline & Autonomy & $\begin{array}{l}\text { Bullen \& Flamholtz (1985); Chia } \\
\text { (2003); Pitman et al. (1989); Furnham } \\
\text { et al. (2009); Currivan (1999): } \\
\text { Hackman \& Oldham (1976) }\end{array}$ \\
\hline & $\begin{array}{l}\text { Varied work } \\
\text { assignments }\end{array}$ & $\begin{array}{l}\text { Carcello et al. (1991); Philips \& Crain } \\
\text { (1996); Pitman et al. (1989); Furnham } \\
\text { et al. (2009); Hackman \& Oldham } \\
\text { (1976) }\end{array}$ \\
\hline & Work significance & $\begin{array}{l}\text { Carcello et al. (1991); Bullen \& } \\
\text { Flamholtz (1985): Hackman \& Oldham }\end{array}$ \\
\hline & & (1976) \\
\hline & Firm policy & $\begin{array}{l}\text { Gammie \& Whiting (2013); Herbohn, } \\
\text { (2004); Larkin et al. (1999) }\end{array}$ \\
\hline \multirow{7}{*}{$\begin{array}{l}\text { Work } \\
\text { environment }\end{array}$} & $\begin{array}{l}\text { Career } \\
\text { development }\end{array}$ & $\begin{array}{l}\text { Nouri \& Parkers (2013); Bullen \& } \\
\text { Flamholtz (1985); Twenge et al. (2010) }\end{array}$ \\
\hline & $\begin{array}{l}\text { Promotional } \\
\text { justice }\end{array}$ & $\begin{array}{l}\text { Gaertner (1999); Herda \& Lavelle } \\
\text { (2012); Furnham et al. (2005); Kim et } \\
\text { al. (1996) }\end{array}$ \\
\hline & $\begin{array}{l}\text { Compensational } \\
\text { justice }\end{array}$ & $\begin{array}{l}\text { Gaertner (1999); Herda \& Lavelle } \\
\text { (2012); Furnham et al. (2005); Kim et } \\
\text { al. (1996) }\end{array}$ \\
\hline & $\begin{array}{l}\text { Performance } \\
\text { evaluation }\end{array}$ & $\begin{array}{l}\text { Pitman et al.(1989); Carcello et al. } \\
\text { (1991): Hackman \& Oldham (1976) }\end{array}$ \\
\hline & Mentoring & Carcello et al. (1991); Herbohn (2004) \\
\hline & $\begin{array}{l}\text { Relationship with } \\
\text { colleagues }\end{array}$ & $\begin{array}{l}\text { Pitman et al. (1989); Twenge et al. } \\
\text { (2010); Furnham et al. (2005) }\end{array}$ \\
\hline & $\begin{array}{l}\text { Organizational } \\
\text { pride }\end{array}$ & Nouri \& Parkers (2013); Knoop (1994) \\
\hline
\end{tabular}

Measurement items (Scale 1=

strongly disagree to $7=$ strongly

agree)

The work as an audit assistant

involves/involved autonomy over my job assignments.

\section{The work as an audit assistant}

involves/involved varying job assignments.

experience/experienced the job assignments as relevant.

I perceive/perceived the firm's policies and routines to be good.

The work as an audit assistant

involves/involved career development.

experience/experienced fair treatment in

regards to promotions.

experience/experienced my wage to be reasonable in comparison to my performance.

\section{The work as an audit assistant}

involves/involved regular performance evaluations.

The work as an audit assistant

involves/involved sufficient support from mentors.

I experience/experienced good relationships with my colleagues.

experience/experienced pride in being a part of the auditing firm.

\section{Original statements}

"Independence - a job that allows me to work autonomously without much supervision." (Furnham, et al., 2009)

"Relatively stable and predictable assignments." (Carcello et al., 1991); "Staff accountants have relatively stable and predictable work assignments." (Philips \& Crain, 1996); "Diversity of job assignments." (Pitman, et al., 1989); "Variety - a job that allows me to get involved in many different kinds of activities."

(Furnham et al., 2009)

"Public accounting involves a minimum amount of menial job responsibilities." (Carcello et al., 1991); "Extent [to which] work is significant." (Bullen \& Flamholtz, 1985)

Own developed statement

"Working for my firm will help my career." (Nouri \& Parkers, 2013)

Opportunity for advancement (Bullen \& Flamholtz, 1985); “A job where the chances for advancement and promotion are good." (Twenge et al., 2010)

"Fairness (people being equitably paid for performance compared to others)" (Furnham et al, 2005): "I am rewarded fairly considering the responsibilities have." (Kim et al., 1996)

"Fairness (people being equitably paid for performance compared to others)" (Furnham et al., 2005): "I am rewarded fairly considering the responsibilities I have." (Kim et al., 1996)

"Not knowing how your performance was valuated." (Pitman, et al., 1989); "Receipt of timely and constructive performance evaluations." (Carcello et al 1991)

"Availability of knowledgeable supervisor to answer questions." (Carcello et al., 1991)

"A job that gives you a chance to make friends." (Twenge, et al., 2010): "Relationships with work colleagues" (Furnham, et al., 2005)

"I am proud to tell others that I am part of this firm." (Nouri \& Parkers, 2013); "Pride in working for this organization." (Knoop, 1994) 
Table II.

Descriptive statistics career change factors

\begin{tabular}{|c|c|c|c|c|c|c|}
\hline \multirow[t]{2}{*}{ Career change factors } & \multicolumn{2}{|c|}{$\begin{array}{l}\text { Current audit } \\
\text { assistants }\end{array}$} & \multicolumn{2}{|c|}{$\begin{array}{l}\text { Former audit } \\
\text { assistants }\end{array}$} & \multirow{2}{*}{$\begin{array}{c}\text { Difference } \\
\text { Mean }\end{array}$} & \multirow{2}{*}{$\begin{array}{c}\text { T-test } \\
\text { Sig. (2-tailed) }\end{array}$} \\
\hline & Mean & Std. Dev. & Mean & Std. Dev. & & \\
\hline Work-life balance & 5.13 & 1.55 & 3.97 & 1.941 & 1.16 & 0.000 \\
\hline Overtime & 4.97 & 1.754 & 3.92 & 1.999 & 1.05 & 0.000 \\
\hline Working hours & 3.58 & 1.845 & 2.9 & 1.813 & 0.68 & 0.008 \\
\hline Expertise & 6.01 & 1.006 & 5.44 & 1.456 & 0.57 & 0.002 \\
\hline Flexibility & 5.87 & 1.365 & 5.32 & 1.655 & 0.55 & 0.013 \\
\hline Autonomy & 4.59 & 1.596 & 4.05 & 1.611 & 0.54 & 0.017 \\
\hline Quality of work & 5.76 & 1.234 & 5.23 & 1.278 & 0.53 & 0.002 \\
\hline Material rewards & 4.14 & 1.848 & 3.62 & 1.796 & 0.52 & 0.039 \\
\hline Perceived fairness & 5.1 & 1.542 & 4.6 & 1.59 & 0.5 & 0.023 \\
\hline Mentoring & 5.13 & 1.572 & 4.65 & 1.61 & 0.48 & 0.032 \\
\hline Organisational Pride & 5.44 & 1.58 & 4.96 & 1.391 & 0.48 & 0.025 \\
\hline Sense of meaning & 4.93 & 1.377 & 4.49 & 1.569 & 0.44 & 0.037 \\
\hline Career development & 6.15 & 1.134 & 5.73 & 1.393 & 0.42 & 0.015 \\
\hline Firm policy & 5.29 & 1.476 & 4.95 & 1.553 & 0.34 & 0.106 \\
\hline Performance review & 4.25 & 1.603 & 4.53 & 1.657 & -0.28 & 0.220 \\
\hline Workload & 4.2 & 1.505 & 3.92 & 1.696 & 0.28 & 0.213 \\
\hline Status and prestige & 4.39 & 1.548 & 4.14 & 1.688 & 0.25 & 0.259 \\
\hline Varied work assignments & 5.64 & 1.431 & 5.41 & 1.436 & 0.23 & 0.249 \\
\hline Work-related travels & 4.02 & 1.801 & 3.79 & 1.615 & 0.23 & 0.354 \\
\hline Stress & 2.71 & 1.223 & 2.59 & 1.362 & 0.12 & 0.489 \\
\hline $\begin{array}{l}\text { Relationship with } \\
\text { colleagues }\end{array}$ & 6.2 & 1.2 & 6.23 & 1.031 & -0.03 & 0.860 \\
\hline Societal benefits & 5.46 & 1.23 & 5.36 & 1.554 & 0.01 & 0.627 \\
\hline & $\mathrm{N}=153$ & & $\mathrm{~N}=78$ & & & \\
\hline
\end{tabular}


Table III.

Principal component analysis

\begin{tabular}{lcccc}
\hline Items & $\begin{array}{c}\text { Component } 1 \\
\text { Work } \\
\text { environment }\end{array}$ & $\begin{array}{c}\text { Component 2 } \\
\text { Work-life } \\
\text { balance }\end{array}$ & $\begin{array}{c}\text { Component 3 } \\
\text { Perceptions of } \\
\text { the profession }\end{array}$ & $\begin{array}{c}\text { Component } 4 \\
\text { Flexibility }\end{array}$ \\
\hline Relationship with colleagues & 0.835 & -0.092 & -0.234 & 0.030 \\
Firm policy & 0.711 & 0.142 & 0.216 & -0.088 \\
Organisational pride & 0.607 & 0.058 & 0.430 & -0.018 \\
Promotional justice & 0.582 & 0.044 & 0.208 & 0.075 \\
Compensational justice & 0.550 & 0.249 & 0.055 & 0.025 \\
Work significance & 0.527 & 0.151 & 0.227 & 0.162 \\
Mentoring & 0.503 & -0.015 & 0.068 & 0.462 \\
Performance evaluation & 0.434 & -0.215 & 0.054 & 0.418 \\
Overtime & 0.077 & 0.815 & -0.050 & 0.149 \\
Working hours & -0.066 & 0.810 & -0.013 & -0.113 \\
Stress & -0.064 & 0.741 & 0.021 & 0.055 \\
Work-life balance & 0.217 & 0.599 & 0.038 & 0.287 \\
Sense of meaning & -0.001 & 0.084 & 0.770 & 0.103 \\
Status and prestige & -0.291 & -0.088 & 0.735 & 0.226 \\
Societal benefits & 0.227 & 0.118 & 0.716 & -0.304 \\
Expertise & 0.145 & 0.001 & 0.713 & 0.004 \\
Career development & 0.309 & 0.014 & 0.412 & 0.229 \\
Flexibility & 0.001 & 0.192 & 0.011 & 0.742 \\
Autonomy & -0.037 & 0.088 & 0.057 & 0.611 \\
Workload & 0.311 & 0.285 & 0.037 & 0.418 \\
Varied work assignments & 0.262 & -0.123 & 0.341 & 0.403 \\
\hline Cronbach's Alpha & 0.874 & 0.791 & 0.784 & 0.685 \\
\hline Extaction Method: Pring & Con & & &
\end{tabular}

Extraction Method: Principal Component Analysis.

Rotation Method: Oblimin with Kaiser Normalization.

Rotation converged in 11 iterations. 
Table IV.

Logistic regression

\begin{tabular}{lccc}
\hline Variables & B & $\begin{array}{c}\text { Std. } \\
\text { Error }\end{array}$ & $\begin{array}{c}\text { Odds } \\
\text { Ratio }\end{array}$ \\
\hline Work environment & -0.059 & 0.213 & 0.942 \\
Work-life balance & $-0.399^{*}$ & 0.203 & 0.671 \\
Perceptions of the profession & $-0.610^{* *}$ & 0.201 & 0.543 \\
Flexibility & $-0.393 \dagger$ & 0.201 & 0.675 \\
Met expectations & $0.375^{*}$ & 0.165 & 1.455 \\
Age & $0.173^{* * *}$ & 0.031 & 1.189 \\
Female & -0.394 & 0.357 & 0.674 \\
Big 4 & $1.091^{* *}$ & 0.390 & 2.976 \\
Office size & 0.001 & 0.001 & 1.001 \\
Tenure & $-0.015^{* *}$ & 0.006 & 0.985 \\
Constant & $-7.964^{* * *}$ & 1.270 & 0.000 \\
Model Chi-2 & $91.184^{* * *}$ & & \\
Classification & $81 \%$ & & \\
Cox \& Snell $\mathrm{R}^{2}$ & 0.326 & & \\
Nagelkerke R & 0.452 & & \\
Hosmer \& Lemeshow & 0.366 & & \\
\hline$* * *$ p $<001 ; *$ p & & & \\
\hline
\end{tabular}

${ }^{* * *} \mathrm{p}<0.001 ;{ }^{* *} \mathrm{p}<0.01 ; * \mathrm{p}<0.05 ; \dagger \mathrm{p}<0.10$ 